\title{
Effects of Guided Inquiry and Cooperative Instructional Strategies on Ss1 Students' Academic Achievement In Conceptual Understanding of Photosynthesis.
}

\author{
Eziyi, Margaret Eke (Mrs.), Mumuni, A. A (Dr. Mrs.) and Nwanekezi, A. U \\ (Dr. Mrs.) \\ Department of Curriculum Studies and Educational Technology, Faculty of Education, University of Port \\ Harcourt, Nigeria.
}

\begin{abstract}
This study investigated the effects of guided inquiry instructional and Cooperative instructional strategies on SS1 students' academic achievement in conceptual understanding of Photosynthesis in Port Harcourt Education Zone of Rivers State, Nigeria. 186 students used for the study were obtained by purposive sampling based on the availability of science laboratory and biology teacher with not less than five years teaching experience. One class of Senior Secondary One (SS1) students from three Co-educational Senior Secondary Schools was randomly assigned to experiment and control groups. The instrument titled for Biology Achievement Test on Photosynthesis (BATOP) was developed, validated and used for data collection. The research questions were answered with Mean and Standard Deviation; while the hypotheses were tested with ANOVA and ANCOVA. Result revealed that 5E guided inquiry instructional strategy proved to be more effective in the teaching and understanding of concepts of Photosynthesis than Cooperative Instructional Strategy and the conventional lecture method; Mean difference between GIIS and CIS= 4.016; GIIS and LM = 19.410. It was recommended that 5E Guided Instructional Strategy should be used to teach the concepts of Photosynthesis so as to improve male and female academic achievement in both internal and external examinations.
\end{abstract}

Keywords: Biology, SS1 Students, Academic Achievement, 5E Guided Inquiry Instruction, Cooperative Instruction, Conceptual Understanding, Photosynthesis, and Gender.

\section{INTRODUCTION}

Biology is one of the three science subjects taught at the Senior Secondary School level in Nigeria."It is the branch of science that involves the study of living things" Ramalingam (2011); Idodo- Umeh (2010). The knowledge of biology is highly indispensable for national development and global competitiveness in areas of medicine, agriculture and health and physical and health education, especially sports, and environmental studies among others. It is a subject for the empowerment of the youth with basic knowledge about their body functionality, inter-relationship with other living things and environmental sustainability. The aim of teaching biology at the Secondary School level is to equip the youth for the challenges in the world and make them executors and advocates of such important knowledge. It is also aimed at giving the youth at the Senior Secondary School level a foundation on which to build further knowledge at the tertiary level of learning. This is stated in the National Policy on Education by the Nigeria Educational Research and Development Council (NERDC) viz: The two broad goals of education in Nigeria are: To prepare the individual for: a) useful living in the society, and (b) for higher education NERDC (2013). These goals are in tandem with the objectives of Senior Secondary School Biology which are: "To prepare students to acquire i) adequate and field skills in biology; ii) meaningful and relevant knowledge in biology; iii) ability to apply scientific knowledge to everyday life matters of personal and community health and agriculture; iv) reasonable and functional scientific attitude" NERDC (2009 p.iv).It is embarrassing that despite the key roles biology is supposed to play in national development in areas of medicine, agriculture, environmental studies and industries, the failure rate at the Senior Schools Certificate Examinations (SSCE) is overwhelming.

Analyses of the SSCE biology results show that though enrolment at the West African Senior Secondary Certificate Examination (WASSCE) and the National Examination Council (NECO) by candidates may be high, the percentage failure has also remained consistently high since year 2012 ( WAEC, 2013); (NECO,2015). Both WAEC and NECO have reported low achievement in biology in 2012, 2013 and 2014 examinations. In 2013, the report of the West African Examination Council (WAEC) Chief Examiner stated that a total population of One Million, Six Hundred and forty-five thousand and forty seven $(1,645,047)$ candidates sat for biology examination in May/June, but less than ten percent $(10 \%)$ of the candidates made a credit in the subject. When the 2013 biology result was compared with that of 2012, the WAEC Chief Examiner noted a 
further decline in performance by the year. He stated that in 2013, May/June, the raw mean score for biology was 18 with a standard deviation of 10.05 , while the raw mean score for 2012 May/June was 20 with a Standard deviation of 11.18. The NECO Chief Examiner's report for 2014 recorded an average score range of $39-58$ over 80 for practical biology (Biology I) and described overall achievement in the theory paper (Biology II) as "generally poor". The chief examiner noted in his report that poor performance has become "the trend in recent years". He concluded that "an insignificant number of candidates excelled" NECO (2015).

Low academic achievement in WAEC biology has been persistent for many years. Obomanu, Nwanekezi and Ekineh's (2014 p.238) research showed that percentage pass at credit level and above in biology at the WASSCE never exceeded fifty percent (50\%) from the year 2000 to 2010 .The 60\%:40\% provision for Science /Technology and Arts/Humanity admission ratio into higher institutions in Nigeria is not being maintained because of low academic achievement in biology and other science subjects at the WASSC and Unified Tertiary Matriculation Examinations (UTME) by candidates. There is need to continue to search for better ways of teaching biology in order to improve student academic achievement at both internal and external examinations and realize the nations educational objectives.

Research studies have pointed out some factors that may be responsible for low achievements of students in biology. The most common factors in literature are teaching methods and strategies, large class size, English language, difficult concepts, large curriculum, inadequate laboratory and instructional materials and teacher qualification among others Mhlamvu (2010); Nwagbo and Okoro (2012); Nworgu and Otum (2013), Obomanu, Nwanekezi and Ekineh (2014); Irinoye, Bamidele, Adetunji, and Awodele (2015).

The researchers of this study tend to agree with a few other researchers who have stood firm to accept that the problem lies with the teaching methods, strategies and approaches. Every science subject has two parts - the practical and the theory aspects. The essence is to provide both inquiry laboratory and theory experiences to the learners thereby making science both interesting and rewarding; but most often biology teachers present biology as knowledge to be memorized. Teachers cumber students with long lectures, large notes and assignments meant to keep the learners busy without positive impact on their cognition and affection.

Some teaching methods and strategies have been proved to be efficacious in the teaching and learning of abstract and difficult concepts in different science subjects than the conventional lecture method including Dramatization, Concept Mapping, Collaborative and Cooperative and Guided Inquiry, among others Onwukwe \& Akuezuilo (2014); Ajaja (2013); Johnson, Johnson \& Holubec (2008); Obomanu, Nwanekezi \& Ekineh (2014); Nwagbo \& Okoro (2012); Ogbu (2010); Hmelo-Silver, Duncan \& Chinn (2006); Onwukwe and Akuezuilo (2014).

\section{LITERATURE REVIEW}

Learning theories which formed the basis of this study were:

- Cognitive Social Learning of Bandura, Kassin (2004), a behaviorist's theory which views personality as a product of a continuous interaction between persons and their environment.

- The cognitivists' theory which advocates that humans generate knowledge and meaning through sequential development of individuals' mental abilities such as mental processes of observation, comprehension, application, analysis and synthesis among others Kalanzis and Cope (2012).

- Constructivism, a philosophy of learning founded on the premise that by reflecting on our experiences we construct our own understanding of the world we live in. Accordingly, knowledge is acquired through involvement with content instead of imitation or repetition Kroll and La Basky, (1996) in Bala and Tandon, (2009). Jean Piaget's assimilation and accommodation mental model Kalanzis and Cope (2012); Jerome Brunner's motive for learning,(infed.org/mobi/Jerome-brunner-and-the process of education, nd. ); David Ausubel's meaningful reception theory of Subsumption (ASA/education/teachers/active.htm); Kassin (2004 p.112) Kumagai (2015); Ausubel, Novak and Hanesian (1986); (infed.com/mobi...);and Orthogonal teaching Axes Cobern, Schuster, Adams, Skjold, Mugaloglu, Benz and Sparks (2014), and Lev Vygotsky's Social Constructivism which sees learning ability as a product of mental capability and a degree of socio-cultural cognition. Notable among Lev Vygotsky's socio-cultural theories is the theory of the Zone of Proximal Development (ZPD) which is achieved by a student through the guidance of a teacher and peers Santrock, (2001); Kalanzis and Cope (2012).

\section{GUIDED INQUIRY INSTRUCTIONAL STRATEGY}

Guided Inquiry Instructional Strategy (GIIS) is a combination of activities involving objects including drawings, charts, specimens and concept maps, posing questions, carrying out investigations in the laboratory, proposing explanations, collecting data, and comparing proposed explanations with new data under the guide of the teacher Kulthau (2010); Kulthau and Todd (2007). Guided inquiry is a type of inquiry that is efficacious for beginners in science such as the Senior Secondary One (SS1) students who cannot be engaged in open inquiry 
because of lack of experience. Senior Secondary One (SS1) is a foundation Senior Secondary class where students are being introduced to Science in compartmentalized form - Biology, Chemistry and Physics- instead of the integrated form science was taught at their Basic level. Failure to use innovative teaching strategies at this level may result into the students detesting science for life. Guided inquiry is suitable and beneficial for learning at the secondary school level of education where students are helped by the teacher to carry out laboratory investigations and classroom inquiries of natural phenomena such as photosynthesis and other studies with the teacher as a guide Kuhlthau (2010); Adeyelami, (2010). Guided inquiry is a strategy used by teachers and instructors to connect to students' world by creating an environment called 'Third Space' Kulthau (2010), which is the gap between what the students know and what the curriculum expects them to know.

Guided inquiry could be carried out with the learning cycles including Karplus learning cycle, the Biological Science Curriculum Studies (BSCS) 5E Learning cycle, and the 7E learning cycle Bing.com (2012). This study adopted the BSCS 5E instructional cycle which consists of: Engagement, Explanation, Exploration, Elaboration and Evaluation Phases, Eisenkraft (2012). Inquiry instruction is student -centred, encourages inclusiveness, very effective in the development of manipulative skills and the development of higher order thinking needed for problem solving Stephenson (2007); Holbrook (2011).

Some empirical studies on the effects of guided inquiry instruction or its combination have been carried out by previous researchers. Irinoye et al (2015) investigated the relative effectiveness of guided inquiry and demonstration methods on students' performance among secondary school students in Ifelodun Local Government Area (LGA) in Osun State, Nigeria. They discovered that students achieved and retained more practical chemistry with guided inquiry instruction than with demonstration method. Obomanu, Nwanekezi and Ekineh (2014) studied the relative effects of Guided inquiry and Collaborative strategy on secondary School students' performance in ecological concepts in Rivers State, Nigeria. Their findings showed that collaboration strategy group obtained higher mean scores than guided inquiry group. Furthermore, Ajaja, (2013), investigated the best strategy for teaching biology among lecturing, Concept mapping, Cooperative learning and 5E learning cycle in Ika South LG of Delta state. The result of his study showed that students in Cooperative and guided inquiry did not significantly differ in their achievement. Also, there was no significant interaction effect between males and females on achievement based on methods of instruction. Inquiry laboratory and lecture method were used by Beals, Krall and Wymer (2012); Tanga (2012); Kilinc (2007) to carry out different divers investigations in different countries. In each case, guided inquiry was more effective in achieving the learning objectives than lecture. Mhlamvu's experience was different from those of other researchers reviewed above in that guided inquiry laboratory was used to investigate students' achievement in Photosynthesis among students and "the performance was generally poor" Mhlamvu (2010). Secondly, there was no observable difference in the mean scores achievement of boys and girls in that study.

\section{COOPERATIVE INSTRUCTIONAL STRATEGY (CIS)}

Cooperative learning as defined by 'Teaching Strategy' (2015) "is a systematic pedagogical strategy that encourages small groups of students to work together for the achievement of common goal". During cooperative instruction students are grouped heterogeneously in fours or fives based on sex, academic ability and tribe/state/race, among others; and work together in small groups in with each individual carrying out an assigned responsibility on a structured learning activity. It encourages inclusiveness and social interaction which is vital in the work place. It is guided by five elements including face-to-face interaction, positive interdependence, individual accountability, group processing and social skills ('Best Practices' of Science Teaching, 2015), Long-Crowell (2015), Johnson and Johnson (2008); Nwagu and Nzewi (2008). Think-PairShare Cooperative instructional strategy is an instructional strategy that develops the thinking ability of students, erodes shyness, promotes gender equality, peaceful co-existence and greater student involvement among others (Australian Catholic University Resource- ACU, 2012); Carin and Sunds (1975 p.10).

Very few empirical studies on cooperative instruction were found. Berger and Hanze (2010) investigated the impact of the group ability in academic performance in a jigsaw cooperative learning comparing homogeneous and heterogeneous cooperative groups. The result showed a higher academic performance by the homogeneous group.Nwagbo and Okoro's (2012) investigation on the effects of interaction pattern on achievement in biology at Obollo Afor Education Zone revealed that the cooperative interaction pattern was the most effective. It also showed that male biology students achieved higher than their female counterparts.

\section{LECTURE METHOD}

Lecture method of teaching is teacher-centered and is profitable in verbal presentation of ideas, concepts, generalizations and facts that need to be covered within a short period in a large class size. Learners are passive listeners; learn by rote and memorization of facts leading to poor retention and poor academic 
achievement Irinoye, Ayodele, Adetunji and Awodele (2015), Obomanu, Nwanekezi and Ekineh (2014); Ajaja (2013); Carin and Sunds (1975). These shortfalls of lecture method of teaching has led educationists the world over to searching for alternative methods that may be used to achieve educational objectives, especially with the present medical, agricultural, economic, social and environmental challenges.

Photosynthesis like other abstract concepts in biology demand laboratory and field work experience as stipulated in the objectives of Secondary Education Biology Curriculum for effective teaching and learning and retention by the students. Photosynthesis is a concept that many biology teachers brush over and whose definition students hardly remember because of its biochemical and biophysical nature and complexity. Photosynthesis has been defined by Idodo- Umeh (2010p.85) as "The process by which carbohydrates or sugars are synthesized in the green parts of the plants containing chlorophyll by combination of Carbon Dioxide $\left(\mathrm{CO}_{2}\right)$ and Water $\left(\mathrm{H}_{2} \mathrm{O}\right)$ with the aid of sunlight energy while Oxygen $\left(\mathrm{O}_{2}\right)$ is given out as a by-product". The concept of photosynthesis is very relevant in our contemporary time because the world today is facing the challenge of Food Shortage, Global Warming and Climate Change which are problems resulting from the emission of much green- house gases into the atmosphere including: Carbon dioxide $\left(\mathrm{CO}_{2}\right)$ which can only be utilized by green plants during Photosynthesis Idodo-Umeh(2010), Aboho, Agbidye, and Asooso (2013 p.52).

Different researches using innovative instructional strategies such as 5E Guided Inquiry, Concept mapping among others, to teach biology have been carried out in Nigeria in some topics and some states, but rarely has any been done on photosynthesis in Senior Secondary One (SS1) in Port Harcourt Local Government Education Zone. This is the gap this study wants to fill. The concept of photosynthesis is a difficult concept for students at this neonatal stage of schooling. It therefore requires the application of innovative teaching and learning strategies, approaches and well-designed laboratory and instructional materials in other to achieve the desired objectives. To achieve a good conceptual understanding of photosynthesis there is need to apply the conceptual change principles by enhancing the active involvement of the students in practical and field experiences where the students will be knowledge builders instead of knowledge consumers Odagboyi, Otuka and Uzoechi (2015). It should encourage the development of the student's critical thinking and innovative attitudes for problem solving in the society. This study investigated the effects of Guided-Inquiry Instructional Strategy (GIIS) and Cooperative Instructional Strategy (CIS) on SS1 students' academic achievement in conceptual understanding of Photosynthesis in Port Harcourt Local Government Education Zone in Rivers State, Nigeria.

\section{AIM AND OBJECTIVES OF THE STUDY}

The aim of this study was to determine the effects of Guided Inquiry and Cooperative Instructional Strategies on the academic achievement of SS1 students in the concepts of photosynthesis. Specifically, the study sought to:

1) Determine the effects of Guided Inquiry Instructional Strategy (GIIS), Cooperative Instructional Strategy (CIS), and Lecture method (LM) on SS1 Students' academic achievement in Biology (Photosynthesis).

2) Compare the academic achievement of male and female SS1 students taught the concepts of photosynthesis in biology using Guided Inquiry Instructional Strategy (GIIS), Cooperative Instructional Strategy and Lecture method (LM).

\section{RESEARCH QUESTIONS}

The study sought to provide answers to the following research questions.

1) What is the effect of Guided Inquiry Instructional Strategy (GIIS), Cooperative Instructional and Lecture Method (LM) on the academic achievement of SS1 students taught the concepts of Photosynthesis?

2) What is the influence of Gender on the academic achievement of SS1 Students taught the concepts of Photosynthesis using GIIS, CIS and LM?

\section{RESEARCH HYPOTHESES}

The following null hypotheses further guided the study and were tested at a probability level of 0.05

$\mathbf{H o}_{1}$ There is no significant difference in the mean academic achievement scores of SS1 students taught the concepts of photosynthesis using Guided Inquiry Instructional Strategy (GIIS), Cooperative Instructional Strategy (CIS), and Lecture Method (LM).

$\mathrm{Ho}_{2}$ There is no significant difference in the mean academic achievement of male and female SS1 students taught the concepts of Photosynthesis using Guided Inquiry Instructional Strategy (GIIS), Cooperative Instructional Strategy (CIS), and Lecture method (LM). 


\section{SIGNIFICANCE OF THE STUDY}

The result of this study is very significant in the following ways:

It will guide especially biology text book writers in their writings. Most Senior Secondary School text books do not contain the basic details on photosynthesis as required by the Senior Secondary School examination bodies which are WAEC and NECO.Curriculum developers, especially NERDC will use it as added resource in improving the teacher and student activity columns in the Senior Secondary School Biology Curriculum. The current biology curriculum expects the teacher to demonstrate experiments to students while the students observe. That does not make the students co-knowledge builders as they gradually lose interest and resort to note taking and rote learning.Students and teachers in secondary schools will benefit from it as it will help them to improve their academic achievement and effectiveness and record better scores at the Senior Secondary Certificate Examinations (SSCE) Biology examinations.

Fellow researchers, resource persons, the Ministry of Education and stakeholders in education, international and local non-governmental organizations (NGOs) among others, will find the result of this study very useful in the improvement of learning experiences in secondary schools and beyond.

$\mathbf{X}$.

SCOPE OF THE STUDY

The scope of this study comprises:

i) Geographical scope

ii) Strategical scope

iii) Content scope

\section{Geographical Scope}

This study was limited to government owned Senior Secondary Schools in Rivers State, Nigeria. The study was based on the concept of photosynthesis as stipulated in the Senior Secondary School One (SS1) Biology Curriculum (NERDC 2009) and West African Senior Secondary Certificate Examination (WASSCE) 2016 Syllabus.

Strategical scope: a) Guided Inquiry Instructional Strategy (GIIS): The Guided Inquiry Instructional Strategy used for the study is the 5E Biological Science Curriculum Study (BSCS) Instructional Model developed by Bybee, R.W; Taylor, J.A; Gardner, A; Van Scotter, P; Gardson, J; Westbok, A; \& Landes, N (2006).

Content Scope: The study covered the following:

i) Photosynthesis- Biochemical nature of photosynthesis

ii) Light and Dark reactions of Photosynthesis

iii) Material and Conditions necessary for photosynthesis (Internal and External conditions).

\section{RESEARCH METHOD}

A quasi-experimental Pretest-Posttest Control group design was adopted for this study. This design is represented diagrammatically as follows:

$\begin{array}{ccccc}\mathrm{E}_{1} & \mathrm{O}_{1} & \mathrm{X}_{1} & \mathrm{O}_{2} & \\ -\mathrm{C} & \mathrm{O}_{1} & & \mathrm{O}_{2}\end{array}$

Where: $\quad \mathrm{E}_{1}=$ Experimental Group; $\quad \mathrm{X}=$ Treatment

$\mathrm{C}=$ Control Group; $\mathrm{O}_{1}$ and $\mathrm{O}_{2}=$ Pretest and Posttest

The population of the study was all the Two Thousand Six hundred and three $(2,603)$ Senior Secondary One (SS1) students in the eight (8) Co-educational Senior Secondary Schools in Port Harcourt Local Government Area (PHALGA) of Rivers State. A sample of one hundred and eighty six (186) SS1 students in three (3) intact classes from three (3) Co-educational Senior Secondary Schools in Port Harcourt Local Government Area (PHALGA) was chosen by purposive sampling technique based on the presence of science laboratory, trained and experienced teachers, co-educational setting. The instrument titled Biology Achievement Test on Photosynthesis (BATOP) was developed and used for data collection. The BATOP comprised of $504-$ point multiple choice objective questions drawn from the content area of study. The Biology Achievement Test questions were selected from West African Senior Secondary Certificate Examination past question papers and biology text books for Senior Secondary Schools based on the content of the study. The content validity of the Biology Achievement test on Photosynthesis (BATOP) was done with the Table of Specification and Bloom's Taxonomy of Cognitive Objectives as follows: 
Knowledge level 15 questions

Comprehension level 15 questions

Application level 10 questions

Analysis level 5 questions

Synthesis level 3 questions

Evaluation level 2 questions

Total 50 questions

The content validity of BATOP was done with the help of my supervisors who are senior lecturers of the University of Port Harcourt, and three of my colleagues in the department of biology who have taught SS1 students for upwards of five years. These people ensured that the content coverage was adequate, language was clear, and scientific terms appropriately used. Their suggestions improved the instrument before its administration.After the corrections, the instruments were pilot tested on SS1 students in a coeducational school that was not selected for the study. The results of the pilot tests were used to edit the final copy of the instrument for spelling mistakes, sentence construction among others. The reliability of the BATOP was done by test retest method. Pearson's product-moment correlation coefficient statistic was used to obtain a reliability of 0.83 . Teachers used for the study (research assistants), were trained on how to use the teaching plans, teaching aids, and laboratory guides successfully. The pretest was administered just before the teachers started teaching the topic of the study. The teaching of the concepts of photosynthesis lasted for four weeks. On the fifth week the post test of BATOP was administered on the two classes of students in the two schools used for the study by the research assistants while the marking and analysis were done by the researchers. Mean, Standard deviations and Percentage were used to answer the research questions, while the hypotheses were analyzed using Analysis of Variance (ANOVA) and Analysis of Covariance (ANCOVA) at 0.05 alpha levels.

\section{RESULTS}

Research Question 1: What are the effects of Guided Inquiry Instructional Strategy (GIIS), Cooperative Instructional Strategy (CIS) and Lecture Method (LM), on the academic achievement of SS1 students in Biology (Photosynthesis)?

Table 1: The Mean Academic Achievement Scores of SS1 Students Based on Instructional Strategies

\begin{tabular}{|c|c|c|c|c|c|c|}
\hline $\begin{array}{l}\text { GROUP } \\
\text { Gain } \% \\
\end{array}$ & $\mathrm{~N}$ & Pretest- $\bar{x}_{1}$ & $\mathrm{SD}_{1}$ & $\begin{array}{ll}- & \\
\text { Posttest- } & \mathrm{SD}_{2}\end{array}$ & Gain mean & score \\
\hline $\begin{array}{l}\text { Experimental } 1 \text { GIIS } \\
69.99 \%\end{array}$ & 64 & 19.79 & 7.16 & 65.94 & 4.86 & 46.15 \\
\hline $\begin{array}{l}\text { Experimental } 2 \text { CIS } \\
62.44 \%\end{array}$ & 58 & 18.31 & 10.42 & 60.86 & 10.37 & 42.55 \\
\hline $\begin{array}{l}\text { Control } \\
45.94 \%\end{array}$ & М 64 & 25.48 & 7.77 & 47.13 & 10.31 & 21.65 \\
\hline
\end{tabular}

GIIS: Guided Inquiry Instructional Strategy CIS: Cooperative Instructional Strategy LM: Lecture Method groups from Pretest to Posttest

Table 1 revealed that before treatment, the GIIS and Lecture groups were almost at the same entry point or behavior with the GIIS and Lecture groups having Pretest Mean scores of 19.79 and 25.48 respectively. However,after the treatment, Guided Inquiry Instructional Strategy (GIIS) and the Lecture Method (LM) recorded Mean Scores of 65.94, and 47.13 respectively.

The mean academic achievement score of GIIS (experimental group1) seems to be higher than that of Lecture Method (control).

Research Question 2: What is the influence of Gender on the academic achievement of SS1 students taught biology (Photosynthesis) using GIIS, CIS and Lecture Method?

The mean and standard deviations of academic achievement scores of male and female students in BATOP is shown in table 2 below 
Table 2: Mean and Standard Deviationsof Pretest and Posttest Scores of Students inConcepts of Photosynthesis Based on Instructional Strategy and Gender

\begin{tabular}{|lllcccccc|}
\hline \multicolumn{1}{|c}{ Group } & Gender & $\mathbf{N}$ & $\begin{array}{c}\text { Pretest } \\
\mathbf{X}_{\mathbf{1}}\end{array}$ & $\mathbf{S D}_{\mathbf{1}}$ & $\begin{array}{c}\text { Posttest } \\
\mathbf{X}_{\mathbf{2}}\end{array}$ & $\mathbf{S D}_{\mathbf{2}}$ & $\begin{array}{c}\text { Mean } \\
\text { Gain }\end{array}$ & Gain \% \\
\hline Experimenta & Female & 19 & 18.74 & 7.19 & 65.11 & 3.78 & 46.37 & $71.22 \%$ \\
l & s & 45 & 20.84 & 7.12 & 66.29 & 5.17 & 45.45 & $68.56 \%$ \\
GIIS & Males & 23 & 17.65 & 10.65 & 58.52 & 12.09 & 40.87 & $69.87 \%$ \\
CIS & Female & 35 & 18.97 & 10.19 & 62.40 & 8.91 & 43.43 & $6958 \%$ \\
& s & & & & & & & \\
Control & Males & & & & & & & \\
LM & Female & 27 & 27.33 & 7.27 & 48.00 & 11.35 & 21.00 & $53.75 \%$ \\
& S & 37 & 23.62 & 8.27 & 46.70 & 9.54 & 23.08 & $49.42 \%$ \\
\hline
\end{tabular}

GIIS: Guided Inquiry Instructional StrategyCIS: Cooperative Instructional StrategyLM: Lecture Method From table 2 above, it could be deduced that although male and female students in the experimental groups (GIIS), CIS, and Control group (Lecture) had almost the same entry point considering their Pretest scores as shown in the table above. The male students in GIIS, CIS experimental groups recorded slightly higher mean scores than their female counterpart with a mean score of 66.29 and 62.40 respectively, against 65.11 and 58.52 for their females. For the control group, the reverse was the case. The female students recorded a mean score of 48.00 while their male counterpart recorded a mean score of 46.07. The table reveals that the male students made a mean score of difference of 23.08 against 21.00 made by the females.

\section{HYPOTHESES}

$\mathrm{Ho}_{1}$ : There is no significant mean difference in the academic achievement of SS1 students taught biology with Guided Instructional Strategy (GIIS), Cooperative Instructional Strategy (CIS) and Lecture Method (LM).

To find out the most effective strategy the BATOP data were further analyzed with Analysis of Covariance (ANCOVA) as shown in table 3.

Table 3: Analysis of Covariance of Students' Pretest and Posttest Achievement Scores. Dependent Variable: Academic Achievement Posttest Scores.

\begin{tabular}{|lllllll|}
\hline \multicolumn{1}{|c}{$\begin{array}{c}\text { Source of } \\
\text { Variables }\end{array}$} & $\begin{array}{c}\text { Type III Sum } \\
\text { of Squares }\end{array}$ & \multicolumn{1}{c}{ Df } & $\begin{array}{c}\text { Mean } \\
\text { Square }\end{array}$ & F & Sig \\
\hline $\begin{array}{l}\text { Corrected } \\
\text { Model }\end{array}$ & $13440.053^{\mathrm{a}}$ & 3 & 4406.684 & 61535 & .000 \\
Intercept & 77937.702 & 1 & 77937.702 & 1088.331 & .000 \\
Pretest & 1253.489 & 1 & 1253.487 & 77.504 & .000 \\
Gender & 12943.786 & 2 & 6471.393 & 90.367 & .000 \\
Error & 13033.409 & 182 & 71.612 & & \\
Total & 650798.000 & 186 & & & \\
Corrected & 26253.462 & 185 & & & \\
total & & & & & \\
\hline
\end{tabular}

a. R Squared $=.504$ (Adjusted R squared $=495$ ).

The calculated F-ratio is 90.367 and significant at $0.00(\mathrm{P}<0.05)$. $\mathrm{Ho}_{1}$ was not accepted. It shows there is a significant difference among the academic achievements of SS1 students taught the concepts of biology using GIIS, CIS and LM. The difference in the mean achievement scores of students taught the concepts of photosynthesis using Guided Instructional Strategy, Cooperative Instructional Strategy and Lecture Method is significant, and therefore cannot be attributed to chance or error. However, further statistical analysis was done with Post Hoc Tests to determine the direction of the difference. 
Table 4: Post Hoc TestMultiple Comparisons: Dependent Variable, Post Achievement Scheffe

\begin{tabular}{|c|c|c|c|c|c|c|}
\hline \multirow[t]{2}{*}{ (I) } & \multirow[t]{2}{*}{ (J) } & \multirow{2}{*}{$\begin{array}{c}\text { Mean } \\
\text { Difference } \\
\text { (I-J) }\end{array}$} & \multirow[t]{2}{*}{$\begin{array}{l}\text { Std. } \\
\text { Error }\end{array}$} & \multirow[t]{2}{*}{ Sig.: } & \multicolumn{2}{|c|}{$\begin{array}{l}95 \% \text { Confidence Interval } \\
\text { for differences }\end{array}$} \\
\hline & & & & & Lower & Upper \\
\hline GIIS & $\begin{array}{l}\text { CIS } \\
\text { LM }\end{array}$ & $\begin{array}{l}4.016^{*} \\
19.410^{*}\end{array}$ & $\begin{array}{l}1.557 \\
1.504\end{array}$ & $\begin{array}{l}.011 \\
.000\end{array}$ & $\begin{array}{l}.943 \\
16.442\end{array}$ & $\begin{array}{l}7.089 \\
22.378\end{array}$ \\
\hline CIS & $\begin{array}{l}\text { GIIS } \\
\text { LM }\end{array}$ & $\begin{array}{l}-4.016^{*} \\
15.394^{*}\end{array}$ & $\begin{array}{l}1.557 \\
1.592\end{array}$ & $\begin{array}{l}.011 \\
.000\end{array}$ & $\begin{array}{l}-7.089 \\
12.252\end{array}$ & $\begin{array}{l}-.943 \\
18.535\end{array}$ \\
\hline LM & $\begin{array}{l}\text { GIIS } \\
\text { GIS }\end{array}$ & $\begin{array}{l}-19.410^{*} \\
-15.394^{*}\end{array}$ & $\begin{array}{l}1.504 \\
1.592\end{array}$ & $\begin{array}{l}.000 \\
.000\end{array}$ & $\begin{array}{l}-22.378 \\
18.535\end{array}$ & $\begin{array}{l}-16.442 \\
-12.252\end{array}$ \\
\hline
\end{tabular}

(I) and (J) represent Instructional Strategies.Based on estimated marginal means*. The mean difference is significant at .05 level

The above analysis shows that Guided Inquiry Instructional Strategy (GIIS) produced significant mean difference of 4.016 and 19.410 over Cooperative Instructional Strategy (CIS) and Lecture Method (LM). Also the mean difference between CIS and GIIS is -4.016 in favour of GIIS; while the mean difference between CIS and LM is 15.394 in favour of CIS. It then follows that there is a significant mean difference between GIIS and LM and also a significant mean difference between CIS and Lecture and GIIS and CIS all to the favour of GIIS $\mathbf{H o}_{2}$ : There is no significant difference in the mean academic achievement scores of male and female SS1 students taught biology using GIIS, CIS and Lecture method.

Table 5: Analysis of Variance (ANOVA) of the Posttests of SS1 femalestudents in GIIS, CIS (Experimental)

\begin{tabular}{|c|c|c|c|c|c|}
\hline & $\begin{array}{c}\text { Sum of } \\
\text { Squares }\end{array}$ & Df & $\begin{array}{l}\text { Means } \\
\text { Square }\end{array}$ & F-cal. & F-crit. \\
\hline Between & 3472.459 & 2 & 1736.229 & 16.577 & 3.13 \\
\hline Groups & & & & & \\
\hline Within Groups & 6912.527 & 66 & 104.735 & & \\
\hline Total & 10384.986 & 68 & & & \\
\hline
\end{tabular}

Table 6: Analysis of Variance between Male students in GIIS, CIS (Experimental) and Lecture (Control)

\begin{tabular}{lccccc} 
& \multicolumn{5}{c}{ Groups } \\
& $\begin{array}{c}\text { Sum of } \\
\text { Squares }\end{array}$ & Df & $\begin{array}{c}\text { Means } \\
\text { Square }\end{array}$ & F-cal. & F-crit. \\
\hline $\begin{array}{l}\text { Between } \\
\text { Groups }\end{array}$ & 8016.745 & 2 & 4008.373 & 57.628 & 3.90 \\
$\begin{array}{l}\text { Within } \\
\begin{array}{l}\text { Groups } \\
\text { Total }\end{array}\end{array}$ & 7929.374 & 114 & 69.556 & & \\
\hline
\end{tabular}

Table 5 shows that the critical value of $F$ with 2 and 66 degrees of freedom at .05 alpha level of significance is 3.13 , while in table 6 the critical value of F with 2 and 114 at .05 level of freedom is 3.90. Since the computed F- value of 16.557 in table 5 which compares the mean academic achievement scores among female SS1 students taught Biology (Photosynthesis) using GIIS, CIS and Lecture F(16.557) is greater than the critical value of F (3.13); and the computed F-value in Table $6 \mathrm{~F}(57.628)$ comparing the academic achievement scores of SS1 male students in GIIS, CIS, and Lecture is greater than the critical value of F (3.09), the null hypothesis is not accepted. Therefore, there is a significant difference among female and male SS1 students taught Biology (Photosynthesis) using GIIS, CIS, and Lecture in favour of those taught with GIIS. 
Table 7: ANCOVA of Gender Effect on Academic Achievements Based on Instructional Strategies. Test of Between Subjects Effects

\begin{tabular}{|llllll|}
\hline \multicolumn{1}{|c}{$\begin{array}{c}\text { Source of } \\
\text { Variables }\end{array}$} & $\begin{array}{c}\text { Type III Sum of } \\
\text { Squares }\end{array}$ & \multicolumn{1}{c}{ Df } & Mean Square & F & Sig \\
\hline Corrected & $62.221 \partial$ & 1 & 62.221 & .547 & .461 \\
Model & 202073.157 & 1 & 202073.157 & 1775.098 & .000 \\
Intercept & 62.221 & 1 & 62.221 & .547 & .461 \\
Gender & 20946.145 & 184 & 113.838 & & \\
Error & 572930.000 & 186 & & & \\
Total & 21008.366 & 185 & & & \\
Corrected Total & & & & & \\
& & & & & \\
\hline
\end{tabular}

$\partial$. R squared $=.003$ (Adjusted R Squared $=-.002$ ).

The calculated F-value is significant at 0.461 level $(\mathrm{P}>0.05) \mathrm{HO}_{2}$ is retained. Gender did not significantly influence achievement of SS1 Students in biology in the three instructional groups.

\section{DISCUSSION OF FINDINGS}

The analysis of the effects of Guided Instructional Strategy (GIIS), Cooperative Instructional Strategy (CIS) and Lecture Method (LM) on the academic achievement of SS1 students showed that there is a significant difference in the mean scores of students taught the concepts of Photosynthesis using the three methods. The Guided Inquiry Instructional Strategy (GIIS) recorded the highest mean followed by the Cooperative Instructional Strategy (CIS). This implies that guided instructional strategy has more positive effect in enhancing understanding of the concept of photosynthesis and in facilitating students' academic achievement in the said concept than the lecture method which is commonly used by most science teachers in teaching science subjects in Nigerian Senior Secondary Schools in Rivers State. This result is in line with Irinoye, Bamidele, Adetunji and Awodele (2015) who investigated the relationship between guided Inquiry and demonstration method on students' performance in practical chemistry in Ifelodun local government area of Osun state, Nigeria and discovered that students achieved and retained more practical chemistry knowledge with guided inquiry than with demonstration. Furthermore, Ajaja (2013), compared the effectiveness of three teaching methods: Lecturing, Concept Mapping and 5E learning cycle on the achievement of SS2 students in biology and discovered that $5 \mathrm{E}$ learning cycle gave $90.7 \%$, Concept Mapping $88.4 \%$ and Lecture method $81.11 \%$. His conclusion was that the $5 \mathrm{E}$ learning cycle was the most suited method for teaching biology in Senior Secondary Schools. On the other hand, Obomanu, Nwanekezi and Ekineh (2014) who studied the effects of Guided Inquiry and Collaborative Strategy on secondary school students' performance in ecological concepts in biology discovered that collaborative groups obtained higher mean scores than Guided Inquiry group.

The result of the data analysis has also shown that students in the Think-Pair-Share Cooperative group recorded high mean scores. Both male and female members recorded a mean gain at the posttest not less than 40. The minimum score of group members was $38 \%$ while the maximum was $80 \%$. The result agrees with the result obtained by Berger and Hanze (2010) that compared the impact of jigsaw cooperative learning of homogeneous and heterogeneous groups on the academic performance of $12^{\text {th }}$ grade Physics students and discovered that homogeneous cooperative group was significantly higher than heterogeneous group.The reason may be that many female students may not have exhibited the needed features for cooperative learning including: Positive interdependence, group processing and social skills. Moreover it was observed that there were more male than female students in each intact class used for the study. The male students may not have given the females enough chance to contribute in the Think-Pair-Share exercise during classes. However, Ajaja (2013); Nwagbo and Okoro (2012); Odagboyi, Otuka and Uzochi (2015), and Igboanugo and Njoku (2015) found that cooperative instructional strategy is more effective in the teaching of science than lecture method just as this study also observed.

This study has shown that:

XV. CONCLUSIONS 
- Guided Inquiry Instructional Strategy (5E model) is the best instructional strategy for teaching difficult biology concepts such as photosynthesis.

- Secondly, student academic achievement is much higher when 5E model of Guided Inquiry Instructional Strategy is usedthan when Think-Pair-Share Cooperative Instructional Strategy or Lecture method is used to teach abstract concepts, especially the concept of Photosynthesis.

- Thirdly, Think-Pair-Share Cooperative Instructional Strategy is very effective in improving student academic achievement in abstract concepts such as Photosynthesis when the elements of cooperative learning are fully applied by group members.

- Fourthly, male students achieve higher academically than their female counterparts under the same condition of instruction.

[1] ASA/education/teachers/active.htm (nd).

[2] Adeyelami, D (2011). Practical Work in School Science: Are the Aims and Objectives being Achieved? Science Teachers Association of Nigeria 52 ${ }^{\text {nd }}$ Annual Conference Proceedings. Okechukwu Abonyi (Ed.). HEBN Publishers.

[3] Aboho,D. A; Agbidye, A and Asooso, L. N (2013). Developing Curriculum on Climate Change at Secondary School level in Nigeria. Nigerian Journal of Curriculum Studies 20 (2) pp. 47-64 Kanoo T. N (ed)

[4] Ajaja, P.O (2013). Which Strategy best suits Biology Teaching? Lecturing, Concept Mapping, Cooperative Learning or Learning Cycle? Electronic Journal of Science Education 17(1), 1-22

[5] Australian Catholic University (AUC). Teaching Centre (2012). Strategies for Collaborative Learning in Large Groups. Retrieved 21-4-2015.

[6] Ausubel, D.P; Novak, J.D \& Hanesian, H (1986). Educational Psychology: A Cognitive View (2nd Edition). New York: Werbel \& Peck.

[7] Bala, N \& Tandon, T. (2009). Constructivism in Science Teaching. An emergent Pedagogy. Science Journal. Retrieved September, 2015.

[8] Beals, A. M; Krall, R. M. \& Wymer, O. L. (2012). Energy Flow through an Ecosystem: Conceptions of the In-Service Elementary and Middle School Teachers. International Journal of Biology Education, 2(1), 5 Retrieved May, 2015.

[9] Berger, R \& Hanze, M (2010). Impact of Groups Ability on Academic Performance.Contemporary Science Education Research: Teaching. A collection of Papers Presented at ESERA 2009 Conference. M. F. Tasar \& Cakmarkci (Eds).

[10] Best Practices of Science Teaching (nd). The Authentic Best Practices in Science Teaching. www.phy.ilstu.edu/ptc/ 31/content/effective/bestpractices.tmml. Retrieved 7/5/20 15 .

[11] Bing.com (2012). The 5E and 7E Instructional Models. Retrieved October, 2015

[12] Brunner, J (nd). The Process of Education. Infed.org/mobi/Jerome-brunner-and-the process of Education. Retrieved August, 2015.

[13] Bybee, R.W; Powell, J.C \& Trowbridge, L.W (2010). Basic Goals of Science. Education. www.education.com/ reference / article / basic goal_science / education. Retrieved 18-01-2015. Retrieved August, 2015.

[14] Carin, A. A. \& Sund, R. B (1975). Teaching Modern Science. Second Edition. Charles E. Merill Publishing Company, Collumbus, Ohio.

[15] Cobern, W.W; Schuster, D; Adams, B; Skjold, B. A; Mugaloglu, E. Z; Bentz, A; \& Sparks Kelly (2014) Pedagogy in Science Teaching Tests: Formative Assessment of Science Teaching Orientation. International Journal of Science Education, 36(13) 2265-2288. Retrieved July, 2015.

[16] Eisenkraft A. (2012). The 5E Instructional Model. https://www.scrib.com/doc/101302949/eisenkraft7e Retrieved September, 2015.

[17] Hmelo-Silver, C. E; Duncan, R. G \& Chinn, C. A. C(2007). Scaffolding and Achievement in Problem Based and Inquiry Learning. A response to Kirschner, Sweller and Clark (2006). Educational Psychologist, 42 (2), 99-107 Lawrence Erlbaum Associates, inc. Retrieved May, 2015.

[18] Holbrook, J (2011). Enhancing Scientific and Technological Literacy (STL): A Major Focus for Science Teaching in Schools. Journal of Science Teachers Association 46(1)

[19] Idodo-Umeh, G. (2010). College Biology for Senior Secondary Schools. Idodo-Umeh Publishers Ltd.

[20] Irinoye, I; Bamidele, E. F; Adetunji, A. A; Awodele, B.A (2015). Relative Effectiveness of Guided Inquiry and Demonstration Method on Students in Secondary Schools in Osün State. Advances in Social Science Research Journal. 2(2), 21-30. Retrieved June, 2015.

[21] Johnson, D. W. \& Johnson, R. T (2008). Introduction to Cooperative Learning. An overview of cooperative Learning. http/www.google.com Retrieved 10/6/ 2015. 
[22] Kalantzis, M. \& Cope, B (2012). New Learning. Second Edition. Elements of a Science Education. Cambridge University Press.

[23] Kassin, S. (2004). Psychology. 4th Edition. Pearson. Prentice Hall.

[24] Kuhlthau, C. C. (2010). Guided Inquiry: School Libraries in the 21st Century. Journal of School Libraries Worldwide 16(1): 17-28. Retrieved $4^{\text {th }}$ August, 2015.

[25] Kumagai, S. (c) 2015). Ausubel's Subsumption Theory_Role_and Nature of Advance Organizers. www.academia. Edu/4865 184. Retrieved 20-05-2015.

[26] Long-Crowell, E. (2015). Cooperative and Collaborative Learning. Study. corn/academy/cooperative and collaborative_learning_the_classroom html Retrieved 9/10/2015

[27] Mhlamvu, N. V. (2010). Conceptual Understanding of Photosynthesis. A Master's Thesis of the Department of Mathematics, Science and Technology Education. University of Zululand, South-Africa. http://zspace.uzulu.ac.za.oai/request?Verb=ListRecrds\&set=hdl-10530

[28] National Examination Council (NECO) (2014). Chief Examiner's Report on Biology.

[29] Nigeria Educational Research and Development (NERDC) (2013). National Policy on Education. NERDC Press.

[30] Nigeria Educational Research and Development Council (NERDC) (2009). Biology Curriculum for Senior Secondary Schools 1 -3. NERDC Press.

[31] Nigeria Educational Research and Development Council (NERDC) (2009). Chemistry Curriculum for Senior Secondary Schools 1-3. NERDC Press.

[32] Nwagbo, C. R. \& Okoro, A. U. (2012). Effects of Interaction Patterns on Achievement in Biology Among Secondary School Students. Journal of Science Teachers Association of Nigeria (JSTAN). 47(1) $22-32$.

[33] Nwagu, E. N \& Nzewi, U. M (2008). Strategies for Teaching Biodegradable Wastes to Primary, Secondary and Higher Education Students. Science Teachers' Association of Nigeria. Environmental Education Series no. 12 pp. 114-120. Peter Okebukola and Ben B. Akpan (Eds.)

[34] Nworgu, L. N. \& Otum, V. V. (2013). Effect of Guided Inquiry with Analogy Instructional Strategy on Students' Acquisition of Science Process Skills. Journal of Education and Practice 4(27). http: I /www.iiste.org/ journal. Retrieved 4/7/20 15

[35] Obomanu, B.J; Nwanekezi A. U. \& Ekineh D. R (2014). Relative Effects of Two forms of Pedagogy on Secondary School Students' Performance in Ecology Concepts. International Journal of Education and Research 2 (10), 237-250.

[36] Ogbu, J. E. (2010). Effects of Classroom Interaction Pattern on Students' Interest in Basic Electricity Journal of the Nigerian Academy of Education Development (JONAED) 6(1) 19-29

[37] Ramalingam S. T. (2011). Modern Biology for Senior Secondary Schools. (Based on New Biology Curriculum). Africans' First Publishers.

[38] Santrock, W. J. (2001). Educational Psychology. McGraw-Hill Higher Education.

[39] Stephenson, N (2007). Introductory Inquiry Based learning. http://www.teachinquiry. corn/index/introduction. Retrieved August, 2015.

[40] Tanga, G. (2012). Guided Inquiry Based laboratory Instructions: Investigation of Critical Thinking Skills; Problem Solving and Implementing Student Roles in Chemistry. A. Ph. D. Dissertation of Iowa State University, USA. Https: / /docs. oogle.corn/ presentation/dll57Q. Retrieved 18-06-2015.

[41] Teaching Streatgies.html (2015). http://serc.corelation.edu/NAGTWorkhops/coursedesign/Tutorial/Strategies.

[42] West African Examination Council (WAEC) (2013). Chief Examiner's Report on BiologyPapers 1 \& 2 